\title{
A retrospective case report on demographic changes of learners at a school for children with Autism Spectrum Disorder in the Gauteng Province
}

\author{
Sumari van Biljon, University of Pretoria.* \\ Alta Kritzinger, University of Pretoria. \\ Salomé Geertsema, University of Pretoria.
}

\begin{abstract}
Limited research has been published about the demographic characteristics of children with Autism Spectrum Disorder (ASD) in South Africa. Describing the profiles of learners from a school for children with ASD may contribute to local knowledge in the field. A retrospective comparative design was utilised to compare the demographic characteristics of learners over two time intervals: 1992-2002 (Group 1, $n=32$ ) and 20032014 (Group 2, n=109). A total of 141 historical admission records in paper-based files were reviewed. Results indicated that there is a large male gender bias (8.4:1) in learners, which increased over the years. The age of the child when parents first became concerned and the age at diagnosis and assessment at school increased over both time periods. There was also an increase in the diversity of home languages after 2002. Parental qualifications decreased, but social class improved in recent years. The low qualification of a mother was associated with an advanced age of the child at school entry. The data serves as a point of reference for future studies about the characteristics of school children with ASD in South Africa.
\end{abstract}

Keywords: Autism Spectrum Disorder (ASD), demographic characteristics, family, Gauteng, gender ratio, learners, special school, case report, South Africa

*Email address: sumsievb@gmail.com.

South African Journal of Childhood Education | 2015 5(1): 42-61 | ISSN: 2223-7674 |৫ UJ

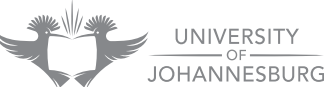




\section{Introduction: Studies on children with Autism Spectrum Disorder in the developing world}

Autism Spectrum Disorder (ASD) in children are highly prevalent, affecting approximately $1 \%$ of the global population (Richmond 2011). Research on the prevalence of ASD has now been conducted in several countries around the globe, including the United States (US) and several countries in Europe and the Western Pacific (Elsabbagh, Divan, Koh et al 2012). In contrast, there are few published studies on autism in Africa (Bakare and Munir 2011).

The prevalence of children with ASD - or what was previously described as pervasive developmental disorder (PDD) - in South Africa is unknown (Bateman 2013; Springer, Van Toorn, Laughton \& Kidd 2013). According to Garcia (2014), the point prevalence of children diagnosed with ASD in the US is estimated to be 1:68. These figures suggest that there could be over 270000 people with ASD in South Africa, with an estimated 5000 new cases per year (Springer et al 2013). Jacklin (2006) described similar numbers, indicating an $8.2 \%$ increase in the number of children presenting with ASD features attending a developmental clinic in Gauteng over the period 19962005. According to Springer et al (2013), it is also not clear whether the increase in the prevalence of ASD in South Africa is related to a heightened awareness of ASD among professionals and parents, or to the broadening of diagnostic criteria since 2000. Given other possible contributing factors in South Africa, such as poverty, illiteracy, the high prevalence of HIV/AIDS and tuberculosis, and a lack of contextual evidence (Penn 2007; Mullis, O'Martin, Kennedy \& Foy 2007), the prevalence of developmental disorder such as ASD in this country may be even higher than in developed countries. In order to determine the future effect of a narrowing of diagnostic criteria, which since 2013 only include two main areas of deficit (APA 2013), it is important to document existing data on children with ASD in South Africa.

According to Mubaiwa (2008), children with ASD and their families often face challenges related to management and diagnosis in South Africa. Limited provision of special needs services in formal education, as well as insufficient material resources in educational settings, poses significant challenges that result in children not receiving the education they need (Pascoe \& Norman 2011). There are only nine dedicated schools in South Africa for children with ASD, and an estimated 135000 children with ASD are not receiving the specialized education they need (Bateman 2013). The few dedicated schools that accommodate children with ASD are overstretched and tend to be inaccessible to the majority of children who need them (Mubaiwa, Aziz, Govender \& Govender 2012). In addition, public transport is generally inaccessible to children with special needs, preventing them from accessing special schools (RSA DoE 2001). These public special schools are mostly situated in urban areas, which is a further disadvantage for children from rural areas. In effect, more children may either be homeschooled or placed in a typical nursery, primary school or independent learners with special educational needs (LSEN) schools. Apart from the challenges related to the accessibility to special schools, the language diversity in South Africa limits first-language education for all. 
Research has yet to be published in South Africa to strengthen the evidence of small studies already conducted locally. Therefore, the researchers aimed to answer the following research question: Has the demographic profile of children with ASD attending a special school in Gauteng changed over the past two decades; and if so, can factors be identified that have contributed to the change?

\section{The inquiry}

The study aimed to compare the learner and family characteristics of children diagnosed with ASD attending a special school in the Gauteng province between 1992-2002 (Group 1) and 2003-2014 (Group 2). The learners constituted the units of analysis. A retrospective comparative design was utilised to compare the demographic characteristics of learners over the two time intervals. The study is a case report, as only one school was investigated.

Written permission was obtained from the Research Ethics Committee of the Faculty of Humanities, University of Pretoria (s28024967); the Gauteng Department of Education (D2014/268); and the principal of the special school for learners with ASD. Informed consent was obtained from parents of the participants currently attending the school.

\section{The case school}

The special school where the inquiry was conducted was established in 1973 and is the largest public school for children with ASD in the Gauteng province. The school is situated in an urban area and currently accommodates 111 learners between the ages of 3 and 18 years (personal communication with school principal). Parents apply for admission to the school by completing an application form that is paper screened by the school assessment team to determine whether the child is a candidate for the school. Candidates usually already have a diagnosis of ASD, and are assessed by the school's multidisciplinary team to determine in which phase they should be placed. The team includes a speech-language therapist, occupational therapist, psychologist and sometimes a psychiatrist, who conducts approximately three weekly assessments. Children who do not have an ASD diagnosis are referred, or else assessed and diagnosed by the multidisciplinary team. There is a long waiting list at the school and a child may not be admitted directly. In such cases, the child is referred to a school for children with special needs until there is an opening. Once admitted, the child is placed into a specific phase according to age and level of functionality. The five phases are reception, foundation, intermediate, senior and school leaving. Each phase has two classes, one for high-functioning children and one for low-functioning children.

\section{Participants}

The target population of the investigation were all the learners admitted to the school from 1992 to 2014. Participants had to comply with the following inclusion criteria: diagnosed with ASD according to the DSM-IV (APA 1994) or DSM-IV® (APA 2000) and 
admitted at the school between 1992 and 2014. The first author reviewed 141 (35.5\%) complete historical records in paper-based files of the total number of 397 children who were admitted to the school during 1992 to 2014. Participants were assigned to one of two groups according to the time interval during which they were admitted: Group 1 $(n=32)$ and Group $2(n=109)$. The available historical admission records included those from the archive and the records of the current learners whose parents completed consent forms. Many records of past learners were lost, but available files contained the complete information required for the study. The researchers thus utilised convenience sampling, realising that there can be no generalisation beyond the sample, but also arguing that such studies have a place in the building of understanding of a phenomenon.

General participant characteristics are depicted in Table 1.

Table 1: General participant characteristics ( $n=141)$

\begin{tabular}{|l|l|c|c|}
\hline \multicolumn{1}{|c|}{ Characteristics } & \multicolumn{1}{|c|}{ Categories } & Frequency & (\%) \\
\hline \multirow{2}{*}{$\begin{array}{l}\text { Age (months) at school admission } \\
\text { (Mean age }=49.5 \text { months) }\end{array}$} & $24-59$ months & 22 & $15.6 \%$ \\
\cline { 2 - 4 } & $60-95$ months & 72 & $51.1 \%$ \\
\cline { 2 - 4 } & $>96$ months & 47 & $33.3 \%$ \\
\cline { 2 - 4 } & TOTAL & 141 & $100 \%$ \\
\hline \multirow{3}{*}{ Gender } & Female & 15 & $10.6 \%$ \\
\cline { 2 - 4 } & Male & 126 & $89.4 \%$ \\
\cline { 2 - 4 } & TOTAL & 141 & 100 \\
\hline
\end{tabular}

As can be seen in Table 1 (1.2), the prevailing gender of the sample was male. The male-female ratio in the study sample was 8.4:1. Upon further investigation, the school principal confirmed the finding and added that the current male bias is even larger, with an 11.7:1 ratio. The gender disparity in our study was considerably higher than that reported by Fombonne (2005) in an epidemiologic study conducted in fourteen developed countries (UK, Denmark, US, Japan, Sweden, Ireland, Germany, Canada, France, Indonesia, Finland, Iceland, Israel and Norway), where the male-female ratio in children with ASD was 4.3:1. The male bias could merely reflect the difficulty of diagnosing ASD in females (New, Triebwasser \& Charney 2008). While classic autism would not be overlooked in females, Asperger syndrome may present as other conditions; for example, borderline personality disorder (ibid) or anorexia (Treasure 2007). Both anorexia and borderline personality disorder includes excessively controlling people or the environment and a degree of self-centredness (New et al 2008; Treasure 2007). Furthermore, Asperger syndrome might be underdiagnosed in females who present with imitation skills or are interested in learning to adapt socially, which allows them to present as 'normal' (Holliday Willey 1999).

Most children in the combined sample entered the school between 6 years 0 months and 7 years 9 months, with some as late as nine years of age. One of the reasons why children might have been admitted so late was that the school had reached its full capacity and was unable to accommodate more learners, so that participants had to wait until there was an opening before they could be admitted. 


\section{Data gathering and data handling}

Prior to the main investigation, the first author visited the special school and reviewed five historical school admission records. These included a questionnaire completed by parents, reports from various professionals, and information about the learner's school progress. During the child's assessment and interview with the parents, missing information was obtained and supplemented to the questionnaire. Based on the information obtained from the parent questionnaire, the researchers were able to formulate a structured electronic checklist, with relevant information being captured from the questionnaire. The data was captured into IBM SPSS (Version 22) in order to facilitate analysis. A data dictionary was compiled to map variables and code procedures.

Basic means, frequency and descriptive tables were constructed to investigate and describe the distribution of the data. These results were presented in tabular and graphical format to aid interpretation. Non-parametric tests were used to identify differences between groups and explore underlying relationships amongst variables. The Pearson chi-square test of independence was employed to compare differences between study groups pertaining more specifically to learners' own and family characteristics. In order to further explore underlying linear relationships between selective variables, Pearson correlation coefficients were calculated. This was done primarily due to traditional chi-square analysis not taking natural ordering of certain variables into account (Howell 2010). Generally, the main aim of the statistical data analysis was firstly to present a profile of learners and their families, and secondly, to identify variables that explain the variation between the two groups. Some tentative generalisations could be presented from the statistical analysis.

\section{Results and discussion}

\section{Learner characteristics}

The characteristics of the participants of Group 1 and Group 2 are illustrated in Table 2.

Table 2: Comparison of participant profiles between Group $1(n=32)$ and Group 2 $(n=109)$

\begin{tabular}{|c|c|c|c|c|c|}
\hline \multirow{2}{*}{ Characteristics } & \multirow{2}{*}{ Categories } & \multicolumn{2}{|c|}{ Frequency } & \multicolumn{2}{|c|}{ (\%) } \\
\hline & & Group 1 & Group 2 & Group 1 & Group 2 \\
\hline \multirow{4}{*}{$\begin{array}{l}2.1 \text { Age (months) } \\
\text { when parents became } \\
\text { concerned about } \\
\text { child's development }\end{array}$} & 24-35 months & 3 & 6 & $9.4 \%$ & $5.5 \%$ \\
\hline & $36-47$ months & 15 & 45 & $46.9 \%$ & $41.3 \%$ \\
\hline & 48-59 months & 6 & 19 & $18.8 \%$ & $17.4 \%$ \\
\hline & 60-71 months & 7 & 26 & $21.9 \%$ & $23.9 \%$ \\
\hline \multirow{2}{*}{$\begin{array}{l}\text { (Group } 1 \text { mean age } \\
=48.8 \text { months; } \\
\text { Group } 2 \text { mean age = } \\
52.3 \text { months) }\end{array}$} & $>72$ months & 1 & 13 & $3.1 \%$ & $11.9 \%$ \\
\hline & TOTAL & 32 & 109 & $100 \%$ & $100 \%$ \\
\hline
\end{tabular}




\begin{tabular}{|c|c|c|c|c|c|}
\hline \multirow{2}{*}{ Characteristics } & \multirow{2}{*}{ Categories } & \multicolumn{2}{|c|}{ Frequency } & \multicolumn{2}{|c|}{$(\%)$} \\
\hline & & Group 1 & Group 2 & Group 1 & Group 2 \\
\hline \multirow{6}{*}{$\begin{array}{l}2.2 \text { Reason why } \\
\text { parents became } \\
\text { concerned about } \\
\text { child's development }\end{array}$} & $\begin{array}{l}\text { Delayed speech } \\
\text { development }\end{array}$ & 20 & 72 & $62.5 \%$ & $66.1 \%$ \\
\hline & Autistic behaviour & 8 & 18 & $25.0 \%$ & $16.5 \%$ \\
\hline & Suspected hearing loss & 1 & 2 & $3.1 \%$ & $1.8 \%$ \\
\hline & Speech regressed & 3 & 15 & $9.4 \%$ & $13.8 \%$ \\
\hline & $\begin{array}{l}\text { Struggling to cope } \\
\text { academically at school }\end{array}$ & 0 & 2 & $0.0 \%$ & $1.8 \%$ \\
\hline & TOTAL & 32 & 109 & $100 \%$ & $100 \%$ \\
\hline \multirow{6}{*}{$\begin{array}{l}\text { 2.3 Type of school } \\
\text { before admission at } \\
\text { special school }\end{array}$} & Mother & 20 & 19 & $62.5 \%$ & $17.4 \%$ \\
\hline & Special school & 8 & 41 & $25.0 \%$ & $37.6 \%$ \\
\hline & Typical nursery school & 3 & 35 & $9.4 \%$ & $32.1 \%$ \\
\hline & Typical primary school & 1 & 11 & $3.1 \%$ & $10.1 \%$ \\
\hline & Day care centre & 0 & 3 & $0.0 \%$ & $2.8 \%$ \\
\hline & TOTAL & 32 & 109 & $100 \%$ & $100 \%$ \\
\hline \multirow{4}{*}{$\begin{array}{l}2.4 \text { Age (months) } \\
\text { when participant was } \\
\text { diagnosed with ASD } \\
\text { (DSM-IV or DSM-IV-TR) } \\
\text { (Group } 1 \text { mean age } \\
=78.5 \text { months; } \\
\text { Group } 2 \text { mean age = } \\
73.7 \text { months) }\end{array}$} & 24-59 months & 4 & 25 & $12.5 \%$ & $20.6 \%$ \\
\hline & 60-95 months & 17 & 49 & $53.1 \%$ & $45.0 \%$ \\
\hline & $>96$ months & 11 & 35 & $34.4 \%$ & $32.6 \%$ \\
\hline & TOTAL & 32 & 109 & $100 \%$ & $100 \%$ \\
\hline \multirow{4}{*}{$\begin{array}{l}\text { 2.5 Participant's } \\
\text { diagnosis according to } \\
\text { DSM-IV or DSM-IV-TR }\end{array}$} & Autism & 28 & 96 & $87.5 \%$ & $88.1 \%$ \\
\hline & PDD & 2 & 8 & $6.3 \%$ & $7.3 \%$ \\
\hline & Asperger's syndrome & 2 & 5 & $6.3 \%$ & $4.6 \%$ \\
\hline & TOTAL & 32 & 109 & $100 \%$ & $100 \%$ \\
\hline \multirow{6}{*}{$\begin{array}{l}2.6 \text { Occupation of } \\
\text { professional involved } \\
\text { in ASD diagnosis }\end{array}$} & Child psychiatrist & 11 & 30 & $34.4 \%$ & $27.5 \%$ \\
\hline & $\begin{array}{l}\text { Speech-language } \\
\text { therapist, occupational } \\
\text { therapist, psychologist, } \\
\text { child psychiatrist }\end{array}$ & 11 & 28 & $34.4 \%$ & $25.7 \%$ \\
\hline & Paediatric neurologist & 9 & 29 & $28.1 \%$ & $26.6 \%$ \\
\hline & Paediatrician & 1 & 14 & $3.1 \%$ & $12.8 \%$ \\
\hline & \begin{tabular}{|l|} 
Neurologist \\
\end{tabular} & 0 & 8 & $0.0 \%$ & $7.3 \%$ \\
\hline & TOTAL & & & $100 \%$ & $100 \%$ \\
\hline
\end{tabular}




\begin{tabular}{|c|c|c|c|c|c|}
\hline \multirow{2}{*}{ Characteristics } & \multirow{2}{*}{ Categories } & \multicolumn{2}{|c|}{ Frequency } & \multicolumn{2}{|c|}{$(\%)$} \\
\hline & & Group 1 & Group 2 & Group 1 & Group 2 \\
\hline \multirow{4}{*}{$\begin{array}{l}2.7 \text { Occupation of } \\
\text { person involved } \\
\text { with referral to the } \\
\text { special school }\end{array}$} & Parents & 5 & 8 & $15.6 \%$ & $7.3 \%$ \\
\hline & $\begin{array}{l}\text { Neurologist/ } \\
\text { paediatric neurologist/ } \\
\text { paediatrician/child } \\
\text { psychiatrist/speech- } \\
\text { language therapist/ } \\
\text { occupational therapist/ } \\
\text { social worker/general } \\
\text { medical practitioner }\end{array}$ & 22 & 66 & $68.8 \%$ & $60.6 \%$ \\
\hline & School support team & 5 & 35 & $15.6 \%$ & $32.1 \%$ \\
\hline & TOTAL & 32 & 109 & $100 \%$ & $100 \%$ \\
\hline \multirow{4}{*}{$\begin{array}{l}2.8 \text { Age (months) } \\
\text { of participant at } \\
\text { team assessment at } \\
\text { special school } \\
\text { (Group } 1 \text { mean age } \\
=65.3 \text { months; } \\
\text { Group } 2 \text { mean age = } \\
75.2 \text { months) }\end{array}$} & 24-59 months & 11 & 23 & $34.4 \%$ & $21.1 \%$ \\
\hline & 60-95 months & 17 & 47 & $53.1 \%$ & $43.1 \%$ \\
\hline & $>96$ months & 4 & 39 & $12.5 \%$ & $35.8 \%$ \\
\hline & TOTAL & 32 & 109 & $100 \%$ & $100 \%$ \\
\hline \multirow{4}{*}{$\begin{array}{l}2.9 \text { Age (months) } \\
\text { of participant } \\
\text { when admitted at } \\
\text { special school } \\
\text { (Group } 1 \text { mean } \\
\text { age = } 72.2 \text { months; } \\
\text { Group } 2 \text { mean age = } \\
78.4 \text { months) }\end{array}$} & 24-59 months & 7 & 15 & $21.9 \%$ & $13.8 \%$ \\
\hline & 60-95 months & 18 & 54 & $56.3 \%$ & $49.5 \%$ \\
\hline & $>96$ months & 7 & 40 & $21.9 \%$ & $36.7 \%$ \\
\hline & TOTAL & 32 & 109 & $100 \%$ & $100 \%$ \\
\hline \multirow{4}{*}{ 2.10 Home language } & Afrikaans/English & 26 & 69 & $81.3 \%$ & $63.3 \%$ \\
\hline & $\begin{array}{l}\text { Other South African } \\
\text { languages: Tshivenda, } \\
\text { isiZulu, Sesotho, } \\
\text { Setswana, isiXhosa, } \\
\text { Xitsonga }\end{array}$ & 5 & 38 & $15.6 \%$ & $34.9 \%$ \\
\hline & $\begin{array}{l}\text { Other (French, } \\
\text { Malayalam, lbo) }\end{array}$ & 1 & 2 & $3.1 \%$ & $1.8 \%$ \\
\hline & TOTAL & 32 & 109 & $100 \%$ & $100 \%$ \\
\hline \multirow{3}{*}{ 2.11 Gender } & Female & 5 & 10 & $15.6 \%$ & $9.2 \%$ \\
\hline & Male & 27 & 99 & $84.4 \%$ & $90.8 \%$ \\
\hline & TOTAL & 32 & 109 & $100 \%$ & $100 \%$ \\
\hline \multirow{6}{*}{ 2.12 Firstborn } & Yes & 15 & 53 & $46.9 \%$ & $48.6 \%$ \\
\hline & No & 17 & 56 & $53.1 \%$ & $51.4 \%$ \\
\hline & TOTAL & 32 & 109 & $100 \%$ & $100 \%$ \\
\hline & Female & 19 & 57 & $59.4 \%$ & $52.3 \%$ \\
\hline & Male & 13 & 52 & $40.6 \%$ & $47.7 \%$ \\
\hline & TOTAL & 32 & 109 & $100 \%$ & $100 \%$ \\
\hline
\end{tabular}




\begin{tabular}{|c|c|c|c|c|c|}
\hline \multirow{2}{*}{ Characteristics } & \multirow{2}{*}{ Categories } & \multicolumn{2}{|c|}{ Frequency } & \multicolumn{2}{|c|}{$(\%)$} \\
\hline & & Group 1 & Group 2 & Group 1 & Group 2 \\
\hline \multirow{6}{*}{$\begin{array}{l}2.13 \text { Speech-language } \\
\text { developmental history }\end{array}$} & Non-verbal & 6 & 16 & $18.8 \%$ & $14.7 \%$ \\
\hline & Verbal & 26 & 93 & $81.3 \%$ & $85.3 \%$ \\
\hline & TOTAL & 32 & 109 & $100 \%$ & $100 \%$ \\
\hline & No speech regression & 18 & 48 & $56.3 \%$ & $44.0 \%$ \\
\hline & Speech regressed & 14 & 61 & $43.8 \%$ & $56.0 \%$ \\
\hline & TOTAL & 32 & 109 & $100 \%$ & $100 \%$ \\
\hline \multirow{3}{*}{ 2.14 Province } & Gauteng & 24 & 91 & $75.0 \%$ & $83.5 \%$ \\
\hline & $\begin{array}{l}\text { Other provinces } \\
\text { (Mpumalanga, } \\
\text { Limpopo, Western } \\
\text { Cape, KwaZulu-Natal, } \\
\text { Northern Cape, Free } \\
\text { State, North West) }\end{array}$ & 8 & 18 & $25.0 \%$ & $16.5 \%$ \\
\hline & TOTAL & 32 & 109 & $100 \%$ & $100 \%$ \\
\hline
\end{tabular}

No statistically significant differences were observed when comparing the age of identification of ASD symptoms between Group 1 and Group 2 ( $p$-value = >0.599). The results in Table 2 (2.1) show that the mean age at which parents became concerned about the development of the participant was 48.8 months in Group 1 and 52.3 months in Group 2. The majority of children in both groups (Group 1: $46.9 \%$ and Group 2: $41.3 \%$ ) were identified by their parents between 36-47 months. Some children were identified as late as $>72$ months, possibly because they were high-functioning. Other studies of parental concerns indicate that the majority recognized atypical development by their child's second birthday (Baghdadli, Pico, Pascal et al 2003; Chakrabarti 2009; Chavarska, Klin, Paul \& Volkmar 2007; De Giacomo \& Fombonne 1998; Young, Brewer \& Pattison 2003). The age at identification of ASD symptoms by parents in our cohort even differed from the age of toddlers at the State Diagnostic and Counselling Center (SDCC) in Iceland, where parents had developmental concerns about their children before the age three years (Jónsdóttir, Saemundsen, Antonsdóttir et al 2011). The results indicate that after 2002, participants were identified later. It appears that the parents in our study may have been unaware that their child had a developmental delay and therefore unable to identify developmental concerns early on, which has implications for policy in basic education, social development and health departments in the country. The results highlight the importance of supporting parents with knowledge about developmental disabilities by means of a coordinated programme for early identification of and intervention for infants and young children with special needs.

There were no statistically significant differences found between the groups regarding the reason why parents became concerned about the development of the participant ( $p$-value $=>0.705)$. The main concern in both Group $1(62.5 \%)$ and Group 2 (66.1\%) was delayed speech in the child. After 2002, more parents became concerned about their child's speech and language development, rather than autistic behaviour. Our results correspond with those of De Giacomo and Fombonne (1998), who also 
reported that the most common parental concern was delayed speech and language development (74.4\%). In our study, only $25.0 \%$ of the parents in Group 1, and $16.5 \%$ of the parents in Group 2, became concerned about the presence of ASD characteristics. The failure to recognise ASD symptoms in their child is confirmed by the result about the advanced age of identification of the child. It appears that many parents in the sample were unfamiliar with ASD before their child was diagnosed, resulting in delayed identification and diagnosis. Another reason why parents became concerned was because they suspected that their child had hearing loss (Group 1: 3.1\% and Group 2: 1.8\%). Some parents reported that their child had regressed speech, and this was the reason why they became concerned (Group 1: 9.4\% and Group 2: 13.8\%). Lastly, parents seldom became concerned because their child was struggling at school (Group 1: 0.0\% and Group 2: 1.8\%).

Statistically significant differences were noted when considering the type of school the participants had attended before being admitted to the special school $(\mathrm{p}$-value $=$ $>0.000$ ) (Table 2: 2.3), with the majority of participants in Group 1 (62.5\%) having stayed with their mothers before being admitted to the special school. In contrast, only $17.4 \%$ of participants in Group 2 stayed with their mothers before being admitted to the school. The result indicated that after 2002, more children went to typical nursery schools rather than staying at home with their mothers. This may be because more mothers had to work to earn an income after 2002, and therefore fewer were at home during the day to care for their children. Data shows that South African labour force participation has increased since 1937 (Trading Economics 2015).

No statistically significant differences were noted among the two groups when considering the age at ASD diagnosis ( $p$-value $=>0.427$ ). The mean age at diagnosis of ASD in Group 1 was 78.5 months, and 73.7 months in Group 2. According to the results, the majority of participants in both Group 1 (53.1\%) and Group 2 (45.0\%) received an ASD diagnosis at age 60-95 months. Some children were diagnosed with ASD as late as >96 months. After 2002, the age at diagnosis of the participants in the sample decreased slightly. The results of our study differ from the findings of a population-based study from thirteen sites in the US, which revealed that the median age of ASD diagnosis was 68.4 months (Shattuck, Durkin, Maenner et al 2009). Moreover, the age at ASD diagnosis differs from a study by Springer et al (2013) in the Western Province, where the mean age at ASD diagnosis was 42 months. Possible explanations for the late age at diagnosis in our study might be limited awareness of developmental disorder such as autism, limited knowledge of (normal) developmental milestones, limited services and schools available in South Africa for children with special needs, and limited space in designated schools.

The entire sample of participants was described according to the criteria listed in the DSM-IV (APA 1994) and DSM-IV ${ }^{\circledR}$ (APA 2000). No statistically significant differences were observed when considering the type of ASD diagnosis between Group 1 and Group 2 (p-value $=>0.914)$. The majority of participants (Group 1: 87.5\% and Group 2: $88.1 \%$ ) were classified as having autism. It appears that the two different editions of the classification system used to diagnose the participants did not result in a difference 
in the type of ASD diagnosed in them. The result may also indicate that the admission criteria at the school remained consistent over the twenty-two-year period covered by the study.

There were no statistically significant differences observed between the two groups when considering the occupation of the professional who made the ASD diagnosis ( $\mathrm{p}$-value $=<0.228)$. Fewer participants in Group $1(3.1 \%)$ than in Group 2 (12.8\%) were diagnosed by a paediatrician. The results indicate that after 2002, more participants were diagnosed by paediatricians and fewer by child psychiatrists, paediatric neurologists and multidisciplinary teams. The reason why more diagnoses were made by paediatricians could be increased awareness of ASD among paediatricians and an increase in paediatricians practicing in the city where the school is located. The results differ from a study conducted at a Child Neuropsychiatry Clinic in Sweden by Anderson, Gilberg and Miniscalco (2013), who reported that comprehensive clinical assessments were conducted primarily by a multidisciplinary team including a psychologist, neurologist, psychiatrist, speech-language therapist and/or other professionals who are qualified to diagnose children with ASD. The results of our study appear to indicate a move away from team-based diagnostic assessments, implying that the assessments may not be as comprehensive as described in the literature. The attendant risks of diagnosis of ASD by a single professional may be a topic for future study.

No statistically significant differences were observed when considering the profession of the person who made the referral to the special school ( $p$-value = $>0.228$ ). More participants in Group 1 (68.8\%) than in Group 2 (60.6\%) were referred to the special school by neurologists, paediatric neurologists, paediatricians, child psychiatrists, speech-language therapists, occupational therapists, psychologists, social workers and general medical practitioners. The results in Table 2 (2.7) indicate that participants who were referred to the school after 2002 were less often referred by professionals and more so by school support teams. The Department of Education only instituted school support teams in 2001, and perhaps such teams are now functioning more widely than in the past (RSA DoE 2001). Some of the professionals referring participants to the special school were the same as those who made the ASD diagnosis. The reason why more participants were referred to the special school by health professionals might be increased awareness of ASD symptoms and where the special school is situated.

Statistically significant differences were noted between Group 1 and Group 2 when considering the age at assessment at the special school ( $p$-value $=>0.034)$. The mean age of assessment at the special school was 65.3 months in Group 1, and 75.2 months in Group 2. The increase in age is a matter for concern, as it decreases the opportunity for timely educational and therapeutic intervention for learners at the school. Furthermore, proportional differences were noted between Group 1 (12.5\%) and Group $2(35.8 \%)$ at the age of assessment at the school $>95$ months. Various factors could have contributed to this, such as a long waiting list at the school. However, these factors have not yet been established in South Africa, and should be determined by future research. The results show that participants assessed after 2002 were on 
average older, and much older than children in developed countries, contrasting sharply with the findings of a study in Atlanta, USA, which found that the median age at assessment for children with ASD was 48 months (Wiggins, Biao \& Rice 2006). The present results also differ from a study by Springer et al (2013) in the Western Cape province. These authors found that the median age at assessment in their study was 56 months. Although data on age of school entry could not be obtained, it appears that children with ASD are diagnosed earlier in middle-income countries than our data indicate. The average age at diagnosis of ASD in Colombia, India, Jamaica, Jordan and Mexico is 45-57 months (Samms-Vaughn 2014).

The South African Schools Act (RSA DoE 1996) allows the school governing body of LSEN schools to develop their own admission policies. The governing body of the school where the research was conducted developed an admission policy stipulating that learners may be admitted throughout the year, and may also be admitted for a trial period of a few months. As learners leave classes, openings become available, which may be filled with other learners of the same age or functionality. No statistically significant differences were noted between Group 1 and Group 2 in terms of age of admittance to the special school ( $p$-value $=>0.235$ ). More participants in both Group 1 (21.9\%) and Group 2 (36.7\%) were admitted at the school at the advanced age of $>96$ months. While not significant, when further exploring the underlying linear relationship of age of participant at school admittance, a similar trend (as with age at assessment) was observed. Similar to the result about the age of assessment at the school, children admitted after 2002 were on average older than those admitted before 2002. As reported by Bateman (2013), there are only nine dedicated public schools in South Africa for children with ASD. Therefore, children with ASD might not be admitted early on, as the few schools that can accommodate them are either overstretched or inaccessible. Establishing more special schools for children with ASD in South Africa may relieve the pressure on the few existing ones.

Although no statistically significant differences were found when comparing the home languages of participants between Group 1 and Group 2 ( $p$-value = >0.122), proportional differences were noted when considering the African languages spoken by the participants in Group 1 (15.6\%) and Group 2 (34.9\%). Furthermore, the results indicated that more participants in Group 1 (81.3\%) and fewer in Group 2 (63.3\%) spoke Afrikaans and English at home. The results showed a change in the profile of learners at the school after 2002; more participants were from African language-speaking families, with a decrease in participants with Afrikaans or English as home language. The home languages spoken represent the demographic profile of the participants in the school, and the increase in African language-speaking children in the school most probably reflects the democratic change in the country. The changes across the two periods appear to relate to environmental changes, in particular political changes in the country. It is positive to see that the school is now providing education to the diversity of children in South Africa.

No statistically significant differences were found when considering the gender of the participants in Group 1 and Group 2 ( $p$-value $=>0.298)$. The prevailing gender of 
both Group 1 (84.4\%) and Group 2 (90.8\%) was male, as already indicated in Table 1 as a salient characteristic of the study sample. However, upon further analysis, the results indicated that the male-female gender ratio in the study was 5.4:1 in Group 1, and 9.9:1 in Group 2; hence the gender bias increased over the two periods. The male gender bias is much higher than reported in a tertiary hospital developmental clinic in the Western Cape Province (3.8:1) by Springer et al (2013) and in a tertiary hospital clinic in KwaZulu-Natal (2.8:1) by Mubaiwa et al (2012). The large gender bias in the sample cannot be explained, and further research is required to investigate the reasons why the school has had more boys than girls over the years.

No statistically significant differences were noted between the groups when considering whether the participant was the firstborn child ( $p$-value $=>0.862$ ). According to Fountain, King and Bearman (2011), 42\% of children with ASD from a clinical sample in California were firstborn. In contrast, our results indicated that more participants from both groups (Group 1: $53.1 \%$, and Group 2: $51.4 \%$ ) were firstborn. Furthermore, no statistically significant differences were noted regarding the gender of the first-born ( $p$-value $=>0.480$ ). More participants in Group $1(59.4 \%)$ than in Group $2(52.3 \%)$ were firstborn females. Similar trends were observed between both groups when considering the firstborn and the gender of the firstborn. The results indicate that the firstborn and the gender of the firstborn in the sample remained the same over the twenty-two-year period.

Table 2 (2.13) shows some aspects of the speech-language developmental history of the participants. No significant differences were noted in terms of participants being verbal $(p$-value $=>0.577)$ or having regressed speech $(p$-value $=>0.223$ ) upon admission at the school. The majority of participants in both Group 1 (81.3\%) and Group 2 (85.3\%) were primarily verbal, while $43.8 \%$ of Group 1 and $56.0 \%$ of Group 2 had regressed speech. The results indicate that the majority of participants were verbal when they entered school over the twenty-two-year period, but after 2002 more participants had regressed speech. These results differ from those of Springer et al (2013), where $72.4 \%$ of the preschool participants in the Western Cape study were non-verbal and $17.2 \%$ had regressed speech. However, the results from our study correspond with an ongoing population-based case-control study in California by Hansen, Ozonoff and Krakowiak (2008), who reported that up to $40 \%$ of children with ASD experience regressed speech. Future research should investigate aspects of the speech-language developmental history of children with ASD in South Africa in depth. Regressed speech or loss of spoken language commonly occurs at 19-21 months, and is considered an obvious 'red flag' for ASD (Webb \& Jones 2009). It will be important to investigate whether parents make use of such an obvious early sign of ASD to seek help earlier in those children who experience regressed speech, in comparison with those who do not lose spoken language.

The province of residence for Group 1 and Group 2 were very similar; hence, no significant differences were noted $(p$-value $=>0.276)$. The majority of participants in both Group 1 (75.0\%) and Group 2 (83.5\%) resided in the Gauteng province. According to the results in Table 2 (2.14), after 2002 more participants resided in the Gauteng 
province than in the other provinces of South Africa. The 2011 population census reported that 12.2 million people reside in the Gauteng province (SSA 2011), indicating a $6.4 \%$ increase in the population of this province since 2001. This is consistent with our finding, where the majority of both groups resided in the Gauteng province. A global increase in children diagnosed with ASD, the establishment of schools in other provinces, and a population increase in the school's feeder province might be some of the reasons for the increase in participants who resided in the Gauteng Province.

In summary, it appears that many of the learner characteristics of the participants had remained stable over the twenty-two-year reporting period of the study, although the school increased its intake per year. The advanced age of participants at the diagnosis of ASD, type of ASD diagnosis, male dominance of participants, gender of the participants who were the firstborn in their families, verbal communication of the participants, and residence in Gauteng province remained the same. Important differences between the two time intervals can be seen in the type of school attended before admission to the special school, increased age when assessed at the school, diversity of home languages, and age of school entry after 2002. During the later time interval, fewer participants stayed at home with their mothers and were assessed and admitted later at the school. Lastly, the participants represented a great diversity in home languages in recent years.

\section{Family characteristics of participants}

The family characteristics of the learners are illustrated in Table 3.

Table 3: Comparison of family characteristics between Group $1(n=32)$ and Group 2 $(n=109)$

\begin{tabular}{|c|c|c|c|c|c|}
\hline \multirow{2}{*}{$\begin{array}{l}\text { Characteristics of the } \\
\text { participant's family }\end{array}$} & \multirow{2}{*}{ Categories } & \multicolumn{2}{|c|}{ Frequency } & \multicolumn{2}{|c|}{$(\%)$} \\
\hline & & Group 1 & Group 2 & Group 1 & Group 2 \\
\hline \multirow{3}{*}{ Siblings or single child } & Single child & 6 & 26 & $18.8 \%$ & $23.9 \%$ \\
\hline & Siblings & 26 & 83 & $81.3 \%$ & $76.1 \%$ \\
\hline & TOTAL & 32 & 109 & $100 \%$ & $100 \%$ \\
\hline \multirow{3}{*}{$\begin{array}{l}\text { Family history of } \\
\text { disabilities or conditions }\end{array}$} & Yes & 4 & 9 & $12.5 \%$ & $8.3 \%$ \\
\hline & No & 28 & 100 & $87.5 \%$ & $91.7 \%$ \\
\hline & TOTAL & 32 & 109 & $100 \%$ & $100 \%$ \\
\hline \multirow{5}{*}{$\begin{array}{l}\text { Father's age (years) when } \\
\text { child was conceived } \\
\text { (Group } 1 \text { mean age = } 30.7 \\
\text { years; Group } 2 \text { mean age } \\
=32.1 \text { years) }\end{array}$} & $20-29$ & 15 & 35 & $46.9 \%$ & $32.1 \%$ \\
\hline & $30-34$ & 7 & 36 & $21.9 \%$ & $33.0 \%$ \\
\hline & $35-39$ & 8 & 30 & $25.0 \%$ & $27.5 \%$ \\
\hline & $40-50$ & 2 & 8 & $6.3 \%$ & $7.3 \%$ \\
\hline & TOTAL & 32 & 109 & $100 \%$ & $100 \%$ \\
\hline
\end{tabular}




\begin{tabular}{|c|c|c|c|c|c|}
\hline \multirow{2}{*}{$\begin{array}{l}\text { Characteristics of the } \\
\text { participant's family }\end{array}$} & \multirow{2}{*}{ Categories } & \multicolumn{2}{|c|}{ Frequency } & \multicolumn{2}{|c|}{$(\%)$} \\
\hline & & Group 1 & Group 2 & Group 1 & Group 2 \\
\hline \multirow{6}{*}{$\begin{array}{l}\text { Father's qualifications } \\
\text { (17 missing values) }\end{array}$} & GR 9/10 & 1 & 2 & $3.7 \%$ & $2.1 \%$ \\
\hline & Matric & 9 & 37 & $33.3 \%$ & $38.1 \%$ \\
\hline & Degree & 12 & 38 & $44.4 \%$ & $39.2 \%$ \\
\hline & Diploma/certificate & 3 & 11 & $11.1 \%$ & $11.3 \%$ \\
\hline & Postgraduate & 2 & 9 & $7.4 \%$ & $9.3 \%$ \\
\hline & TOTAL & 27 & 97 & $100 \%$ & $100 \%$ \\
\hline \multirow{4}{*}{$\begin{array}{l}\text { Father's social class } \\
\text { according to occupation } \\
\text { (17 missing values) }\end{array}$} & $\mathrm{A} / \mathrm{B}$ & 15 & 41 & $55.6 \%$ & $42.3 \%$ \\
\hline & C & 11 & 43 & $40.7 \%$ & $44.3 \%$ \\
\hline & $\mathrm{D} / \mathrm{E}$ & 1 & 13 & $3.7 \%$ & $13.4 \%$ \\
\hline & TOTAL & 27 & 97 & $100 \%$ & $100 \%$ \\
\hline \multirow{3}{*}{ Marital status of mother } & Single & 6 & 28 & $18.8 \%$ & $25.7 \%$ \\
\hline & Married & 26 & 81 & $81.3 \%$ & $74.3 \%$ \\
\hline & TOTAL & 32 & 109 & $100 \%$ & $100 \%$ \\
\hline \multirow{5}{*}{$\begin{array}{l}\text { Mother's age (years) } \\
\text { when child was conceived } \\
\text { (Group } 1 \text { mean age }=28.2 \\
\text { years; Group } 2 \text { mean age } \\
=28.8 \text { years) }\end{array}$} & $20-29$ & 20 & 57 & $62.5 \%$ & $52.3 \%$ \\
\hline & $30-34$ & 9 & 37 & $28.1 \%$ & $33.9 \%$ \\
\hline & $35-39$ & 1 & 15 & $3.1 \%$ & $13.8 \%$ \\
\hline & $40-50$ & 2 & 0 & $6.3 \%$ & $0.0 \%$ \\
\hline & TOTAL & 32 & 109 & $100 \%$ & $100 \%$ \\
\hline \multirow{6}{*}{$\begin{array}{l}\text { Mother's qualifications } \\
\text { (1 missing value) }\end{array}$} & GR 9/10 & 1 & 1 & $3.1 \%$ & $0.9 \%$ \\
\hline & Matric & 17 & 45 & $53.1 \%$ & $41.7 \%$ \\
\hline & Diploma/certificate & 10 & 34 & $31.3 \%$ & $31.5 \%$ \\
\hline & Degree & 4 & 23 & $12.5 \%$ & $21.3 \%$ \\
\hline & Postgraduate & 0 & 5 & $0.0 \%$ & $4.6 \%$ \\
\hline & TOTAL & 32 & 108 & $100 \%$ & $100 \%$ \\
\hline \multirow{4}{*}{$\begin{array}{l}\text { Mother's social class } \\
\text { according to occupation } \\
\text { (1 missing value) }\end{array}$} & $A / B$ & 4 & 29 & $12.5 \%$ & $26.9 \%$ \\
\hline & $\mathrm{C}$ & 9 & 41 & $28.1 \%$ & $38.0 \%$ \\
\hline & $\mathrm{D} / \mathrm{E}$ & 19 & 38 & $59.4 \%$ & $35.2 \%$ \\
\hline & TOTAL & 32 & 109 & $100 \%$ & $100 \%$ \\
\hline
\end{tabular}

Results in Table 3 (3.1) show that no statistically significant differences were noted between Group 1 and Group 2 when considering whether the participant had siblings or was a single child ( $\mathrm{p}$-value $=>0.545)$. The majority of participants in both Group 1 (81.3\%) and Group 2 (76.1\%) had siblings; therefore the results concerning the number of siblings in participants' families therefore remained the same over the twentytwo-year reporting period. According to Ozonoff, Young, Carter et al (2011) having an older biological sibling with ASD increases the recurrence rate of ASD. The results may indicate that parents were not aware of the risk of ASD recurrence in siblings, and therefore did not halt reproduction after diagnosis of their affected firstborn child (Ozonoff et al 2011). As already indicated, most parents in our sample had not recognised ASD symptoms in their child before diagnosis.

No statistically significant differences were observed between Group 1 and Group 2 in family history of disabilities or conditions ( $p$-value $=<0.466$ ). Few participants in both 
Group 1 (12.5\%) and Group 2 (8.3\%) reported a family history of disabilities or conditions, such as psychological disorder, language disorder, ASD and epilepsy. After 2002, fewer families reported a history of disabilities or conditions. Our results do not agree with those of the study by Springer et al (2013), who found that $34.4 \%$ of participants had a family history of conditions or disabilities.

No statistically significant differences were found between Group 1 and Group 2 when considering the age of the father at the birth of participants ( $p$-value $=>0.452$ ). The mean age of the father at the birth of the participants was 30.7 years in Group 1 and 32.1 years in Group 2.

No statistically significant differences were found ( $p$-value $=>0.963$ ) in terms of the qualifications of participants' fathers, as $44.4 \%$ of the fathers in Group 1 and $39.2 \%$ of the fathers in Group 2 had a degree. However, the results show that for learners admitted to the school after 2002, fewer fathers had obtained a degree. Fountain et al (2011) found that children with more educated parents are diagnosed with ASD earlier. An increased awareness of developmental delays and different help-seeking strategies, as well as improved ability to gain early access to professionals, can be ascribed to parents being educated (Laughton, Springer, Grove et al 2010).

Social class was determined by grading the occupations of the participants' parents by using the National Readership Survey ' $A B C 1$ ' demographic profiling system, also known as the social grade definitions (http://www.businessballs.com). Although no statistically significant differences were observed ( $p$-value $=>0.266$ ), more fathers in Group 1 (55.6\%) than in Group 2 (42.3\%) were from social class A (upper class; that is, high managerial, administrative or professional) or B (middle class; that is, intermediate managerial, administrative or professional). The results in Table 3 (3.5) show that after 2002, fewer fathers were from social class A or B, and more were from social class $C$ (lower middle class or skilled manual workers), D (working class), or E (unemployed). A study conducted by Fountain et al (2011) investigated individual and communitylevel factors associated with ASD in children across ten birth cohorts in California. The researchers found that children from families with high socio-economic status (SES) were diagnosed earlier than children from low SES families (Fountain et al 2011). Our results do not correspond with this finding, because even if their fathers were from social classes A or B, participants were not diagnosed with ASD at an early age.

In terms of marital status of the mother, the mothers of the participants in both groups were primarily married (Group 1: $81.3 \%$, and Group 2: $74.3 \%$ ); therefore, no statistically significant differences were noted $(p$-value $=>0.420)$. The results indicate that after 2002, fewer mothers were married, and suggest that in recent years more learners were being raised by a single parent, usually a mother, with little indication of live-in fathers. The marital status of parents with children with ASD in South Africa should be investigated in future research. Single parenthood may indicate a need for additional support when a child has ASD.

A statistically significant difference was noted between Group 1 and Group 2 when considering the age of the mother at the birth of the participant ( $p$-value $=>0.019$ ). 
The mean age of the mother at the birth of the participant was 28.2 years for Group 1 , and 28.8 years for Group 2. Furthermore, results indicated that fewer participants in Group 1 (3.1\%) than in Group 2 (13.8\%) had mothers who were aged 35-50 years at the time of their birth. A cohort study conducted by Durkin, Maenner, Newschaffer et al (2008) in the US found that the odds of developing ASD were significantly reduced for parental age $<20$, and increased for maternal age $>35$. The results of our study suggest that after 2002, mothers were on average older, and might therefore have been at risk of having children with ASD. Shattuck et al (2009) reported that delayed identification and diagnosis of ASD were associated with younger maternal age at the birth of the child. The reason may be that younger mothers may not have adequate knowledge of ASD; hence, they are unable to recognise developmental concerns (ibid). Future research in South Africa should determine whether our results regarding the age of mothers at the birth of children with ASD are similar to that of mothers with children diagnosed with other developmental disabilities.

Although no statistically significant differences were observed with regard to the qualifications of participants' mothers ( $p$-value $=<0.401$ ), an educational level of senior school certificate (matric) was documented in 53.1\% of mothers in Group 1 and 41.7\% of mothers in Group 2. Upon further analysis of the underlying linear relationship between the qualification of the mother and the year the child was admitted, statistically significant differences were noted ( $p$-value $=<0.059)$. The results show that after 2002, fewer mothers had a senior school certificate (matric), and that the qualification of the mother had an influence on the year the participant was admitted to the school. The father's educational level was also lower after 2002.

Most mothers in both Group 1 (59.4\%) and Group 2 (35.2\%) were from social class D (working class) or E (unemployed) families. The results showed a statistically significant difference when considering the social class of the mother. After 2002, more mothers were from social classes A (upper middle class), B (middle class), and $C$ (lower class/skilled working class). Although the social class of the mothers were relatively high, the participants were not diagnosed earlier. Therefore, our results do not agree with those of Fountain et al (2011), who found that children from high socio-economic status (SES) families were diagnosed earlier than children from low SES backgrounds. When considering the mothers' lower educational levels after 2002, the increase in their social class after 2002 appears surprising. Further research should be conducted regarding the influence of the social class of mothers and fathers of children with ASD.

In summary, it appears that many of the family characteristics of the learners had remained stable over the twenty-two-year reporting period of the study. Having a sibling or being the only child, and having a family history of conditions or disabilities remained the same. Important differences between the two time intervals can be seen in the educational qualifications of the mother and the year the child was admitted to the special school, the age of the mother at the birth of the participant, and the social class of the mother according to her occupation. During the later time interval, mothers were older at the birth of the participant and more mothers were from 
the upper middle class or middle class, yet less educated. Lastly, a low educational qualification of the mother appears to bear a relationship to the advanced age at which the child was admitted to the school.

\section{Conclusion: Towards earlier diagnosis and early intervention}

Mubaiwa (2008) found that children with ASD and their families often face challenges related to management and diagnosis in South Africa. The same challenges are also faced by families elsewhere, and despite increasing evidence that ASD can be identified and diagnosed accurately in young children, the age of diagnosis, on average, remains delayed (Lord, Risi, DiLavore et al 2006; Sansosti, Lavik \& Sansosti 2012). The most important consequence of delayed diagnosis of ASD in children may be missed early intervention opportunities during the period of high neuroplasticity (ManningCourtney, Brown, Molloy et al 2003). Limited provision of special needs services in formal education in South Africa, as well as insufficient material resources in the educational setting, poses significant challenges that result in children not receiving the education they need (Pascoe \& Norman 2011). There are only nine dedicated schools in South Africa for children with ASD, which means that an estimated 135000 children with ASD are not receiving the specialised education they need (Bateman 2013). These special schools are mostly situated in urban areas, which is a further disadvantage for children with ASD in rural areas. In effect, more children from rural areas may either be homeschooled or placed in a typical nursery or primary school than those in cities (Attwood 2006). As a result, these children are not prepared for the specialised school setting and unable to reach their full potential. The special school selected for this study is therefore an extremely valuable educational asset in Gauteng to parents of children with ASD.

\section{References}

Anderson, G.N., Gilberg, C. \& Miniscalco, C. 2013. Autism in pre-schoolers: Does individual clinician's first visit diagnosis agree with final comprehensive diagnosis? The Scientific World Journal. Retrieved from http://dx.doi.org/10.1155/2013/716267 (accessed 16 July 2014).

APA (American Psychiatric Association). 1994. Diagnostic and statistical manual of mental disorder: DSM-IV. Washington, DC: APA.

APA (American Psychiatric Association). 2000. Diagnostic and statistical manual of mental disorder: DSM-IV-TR. Washington, DC: APA.

APA (American Psychiatric Association). 2013. Diagnostic and statistical manual of mental disorder: DSM-5. Washington, DC: APA.

Attwood, T. 2006. The complete guide to Asperger's syndrome. London: Jessica Kingsley Publishers. 
Baghdadli, A., Pico, M.C., Pascal, C., Pry, R. \& Aussiloux, C. 2003. Relationship between age of recognition of first disturbances and severity in young children with autism. European Child and Adolescent Psychiatry, 12(3):122-127.

Bakare, M.O. \& Munir, K.M. 2011. Autism spectrum disorder (ASD) in Africa: A perspective. African Journal of Psychiatry, 14(3):208-210.

Bateman, C. 2013. Autism - mitigating a global epidemic. The South African Medical Journal, 103(5):276-277.

Business balls demographics classification glossaries. Retrieved from http://www. businessballs.com/demographicsclassificationn.html (accessed 10 October 2014).

Chakrabarti, S. 2009. Early identification of autism. Indian Pediatrics, 46(5):412-414.

Chavarska, K., Klin, A., Paul, R. \& Volkmar, F. 2007. Autism spectrum disorder in the second year: Stability and change in syndrome expression. Journal of Child Psychology and Psychiatry, 48(2):128-138.

De Giacomo, A. \& Fombonne, E. 1998. Parental recognition of developmental abnormalities in autism. European Child and Adolescent Psychiatry, 7(3):131-136.

DSM-IV-TR®. Washington, DC: APA.

Durkin, M.S., Maenner, M.J., Newschaffer, C.J., Lee, L.C, Cunniff, C.M., Daniels J.L., Kirby, S.R., Leavitt, L., Miller, L., Zahorodny, W. \& Schieve, L.A. 2008. Advanced parental age and the risk of autism spectrum disorder. American Journal of Epidemiology, 168(11):1268-1276.

Elsabbagh, M., Divan, G., Koh, Y., Kim, Y., Kauchali, S., Marcín, C., Montiel-Nava, C., Patel, V., Paula, C.S., Wang, C., Yasamay, M.T. \& Fombonne, E. 2012. Global prevalence of autism and other pervasive developmental disorder. Autism Research, 5(3):160-179.

Fombonne, E. 2005. Epidemiology of autistic disorder and pervasive developmental disorder. Journal of Clinical Psychiatry, 66(10):2-8.

Fountain, C., King, M.D. \& Bearman, S.B. 2011. Age of diagnosis for autism: individual and community factors across 10 birth cohorts. Journal of Epidemiology \& Community Health, 65(6):503-510.

Garcia, T. 2014. Child Life Specialists' Reflections of Children with Autism in the Healthcare Setting. Unpublished MA thesis. San Fransisco, CA: Mills College.

Hansen, R.L., Ozonoff, S. \& Krakowiak, P. 2008. Regression in autism: Prevalence and associated factors in the CHARGE study. Ambulatory Pediatrics Journal, 8(1):25-31.

Holliday Willey, L. 1999. Pretending to be normal: Living with Asperger's syndrome. London, UK: Jessica Kingsley Publishers.

Howell, D.C. 2010. Statistical methods for psychology. Belmont, CA: Cengage Learning.

Jacklin, L. 2006. The changing profile of autism in a clinic for children with developmental delay: A ten year survey. Paper presented at Autism Safari 2006: $2^{\text {nd }}$ World Autism Congress \& Exhibition, Cape Town. 
Jónsdóttir, S.L., Saemundsen, E., Antonsdóttir, I.S., Sigurdardóttir, S. \& Ólason, D. 2011. Children diagnosed with autism spectrum disorder before or after the age of 6 years. Research in Autism Spectrum Disorder, 5(1):175-184.

Kogan, M.D., Blumberg, S.J., Schieve, L.A., Boyle, C.A., Perrin, J.M., Ghandour, R. M. \& Van Dyck, P.C. 2009. Prevalence of parent-reported diagnosis of autism spectrum disorder among children in the US, 2007. Pediatrics, 124(5):1395-1403.

Laughton, B., Springer, P.E., Grove, D., Seedat, S., Cornell, M., Kidd, M., Madhi, S.A. \& Cotton, M.F. 2010. Longitudinal developmental profile of children from low socio-economic circumstances in Cape Town, using the 1996 Griffiths Mental Developmental Scales. South African Journal of Child Health, 4(4):106-111.

Lord, C., Risi, S., DiLavore, P.S., Schulman, C., Thurm, A. \& Pickles, A. 2006. Autism from 2 to 9 years of age. Archives of General Psychiatry, 63(6):694-701.

Manning-Courtney, P., Brown, J., Molloy, C.A., Reinhold, J., Murray, D., SorensenBurnworth, R., Messerschmidt, T., \& Kent, B. 2003. Diagnosis and treatment of autism spectrum disorder. Current Problems in Pediatric and Adolescent Health Care, 33(9):283-304.

Mubaiwa, L. 2008. Autism: Understanding basic concepts. South African Journal of Child Health, 2(1):6-7.

Mubaiwa, L., Aziz, L., Govender, R. \& Govender, V. 2012. Pervasive developmental disorder: Clinical characteristics and outcome in African children. Journal of Developmental Medicine \& Child Neurology, 54(suppl 4):151.

Mullis, I.V.S., O'Martin, M., Kennedy, A.M. \& Foy, P. 2007. IEA's progress in international reading literacy study in primary schools in 40 countries. Chestnut Hill, MA: TIMSS \& PIRLS International Study Centre, Boston College.

New, A.S., Triebwasser, J. \& Charney, D.S. 2008. The case for shifting borderline personality disorder to Axis I. Biological Psychiatry Journal, 64(8):653-659.

Ozonoff, S., Young, G.S., Carter, A., Messinger, D., Yirmiya, N., Zwaigenbaum, L. \& Stone, W.L. 2011. Recurrence risk for autism spectrum disorder: A baby sibling research consortium study. Journal of Pediatrics, 128(3):488-495.

Pascoe, M. \& Norman, V. 2011. Contextually-relevant resources in speech-language therapy and audiology in South Africa: Are there any? South African Journal of Communication Disorder, 58(1):2-5.

Penn, C. 2007. 'Don't give me the theory, just tell me what to do in therapy!' The slippery slope challenge for the South African professions of speech-language pathology and audiology. South African Journal of Communication Disorder, 54:13-17.

Richmond, A.S. 2011. Autism spectrum disorder: A global perspective. Perspectives on Global Issues in Communication Sciences and Related Disorder, 1(2):39-46.

RSA DoE (Republic of South Africa. Department of Education). 1996. South African Schools Act 84 of 1996. Pretoria:: Department of Education.

RSA DoE (Republic of South Africa. Department of Education). 2001. Education White Paper 6. Special Needs Education: Building an inclusive education and training system. Pretoria: Department of Education. 
Sansosti, F.J., Lavik, K.B. \& Sansosti, J.M. 2012. Family experiences through the autism diagnostic process. Focus on Autism and Other Developmental Disabilities, 27(2):81-92.

Samms-Vaughn, M.E. 2014. The status of early identification and early intervention in autism spectrum disorder in lower- and middle-income countries. International Journal of Speech-Language Pathology, 16(1):30-35.

Shattuck, P.T., Durkin, M., Maenner, M., Newschaffer, C., Mandell, D.S., Wiggins, L., Lee, L., Rice, C., Giarelli, E., Kirby, R., Baio, J., Pinto-Martin, J. \& Cuniff, C. 2009. Timing of identification among children with an autism spectrum disorder: Findings from a population-based surveillance study. Journal of the American Academy of Child and Adolescent Psychiatry, 45(5):474-483.

Springer, P.E., Van Toorn, R. , Laughton, B. \& Kidd, M. 2013. Characteristics of children with pervasive developmental disorder attending a developmental clinic in the Western Cape Province, South Africa. South African Journal of Child Health, 7(3):95-99.

SSA (Statistics South Africa). 2011. Census 2011. Retrieved from http://www.statssa.gov. za/publications/p03014/p030142011 (accessed 15 September 2014).

Trading Economics. 2015. South Africa Employed Persons 1973-2015. Retrieved from http://www.tradingeconomics.com/south-africa/employed-persons (accessed 15 September 2014).

Treasure, J.L. 2007. Getting beneath the phenotype of anorexia nervosa: The search for viable endophenotypes and genotypes. Canadian Journal of Psychiatry, 52(4):212-219.

Webb, S.J. \& Jones, E.J.H. 2009. Early identification of autism. Early characteristics, onset of symptoms, and diagnostic stability. Infants and Young Children, 22(2):100-118.

Wiggins, L.D., Biao, J. \& Rice, C. 2006. Examination of time between first evaluation and first autism spectrum diagnosis in a population-based sample. Journal of Developmental and Behavioral Pediatrics, 27(2):S79-S87.

Young, R.L., Brewer, N. \& Pattison, C. 2003. Parental identification of early behavioural abnormalities in children with autistic disorder. Autism, 7(2):125-143. 